PATHOGENETIC FEATURES OF VASCULAR-ENDOTHELIAL DISFUNCTION OF PATIENTS WITH A PEPTIC GASTRIC AND DUODENUM ULCER COMPARING WITH A HYPERPIESIS AND DIABETES MELLITUS 2, WAYS OF CORRECTION

\title{
Sithinska Inna
}

HESEU «Bukovinian State Medical University», Chernivtsi, Ukraine

\section{ПАТОГЕНЕТИЧНІ ОСОБЛИВОСТІ СУДИННО-ЕНДОТЕЛІАЛЬНОЇ ДИСФУНКЦІЇ У ХВОРИХ НА ПЕПТИЧНУ ВИРАЗКУ ШЛУНКА ТА ДВАНАДЦЯТИПАЛОЇ КИШКИ У ПОЄДНАННІ 3 АРТЕРІАЛЬНОЮ ГІПЕРТЕНЗІЄЮ І ЦУКРОВИМ ДІАБЕТОМ ТИПУ 2, ШЛЯХИ КОРЕКЦІЇ}

\section{Сіцінська Інна}

Received 26. 6. 2017

The influence of Helicobacter pylori strains leads to changes in lipid profile and content of the adhesion molecules in patients with gastric ulcer and duodenal ulcer in combination with diabetes and hypertension type 2. Correction which is carried out antihacker drugs and a diet that includes flax seed, which has not only the function of healing, but also improve lipid metabolism and antioxidant effect. The purpose of this study was to evaluate the vascular endothelial function in patients with peptic ulcer of stomach and duodenal ulcers combined with arterial hypertension and diabetes mellitus type 2 with subsequent correction. Considering the change of the disturbances of lipid profile and content of the adhesion molecules in addition to offered diet in this disease it is necessary to take flax seeds in the form of tinctures, fruit drinks etc. The main properties of which is to improve peristalsis, the saturation of the organism with various amino acids, manganese, potassium, magnesium and essential fatty acids omega-3, omega- 6 and omega-9. Lignans present in the shell and play the role of antioxidant system and reduce cholesterol with long-term administration. The increasing of insulin secretion and the development of atherosclerotic process due to increased LDL synthesis, which is regulating by the enzyme lopreato (LPL), reduces the concentration of HDL. Minimally oxidized LDL increased expression of adhesion molecules (ICAM, VCAM). Therefore, the pathogenetic relationship of Helicobacter pylori with the development of hypertension and type 2 diabetes patients PWS and DPK will reveal the initial changes of the vessels and the endothelium that will help you effectively choose treatment.

Keywords: gastric; ulcer; hypertensis; diabetes; Helicobacter pylori

\section{Вступ}

За останні роки значно змінилося розуміння механізмів регуляції метаболічних процесів на молекулярно-генетичному рівні, що призвело до перегляду традиційних уявлень

*Corresponding author: Inna Sithinska, HESEU «Bukovinian State Medical University», Chernivtsi, Ukraine, 
про клітинну фізіологію. Глибше розуміння патогенезу артеріальної гіпертензії (АГ) та інших супутніх їй захворювань - інсулінорезистентності (IP), гіперінсулінемії (ГI), дисліпідемії (ДЛ) (Бабак та ін. 2011), а також невід'ємної ролі інфекції Helicobacter pylori у розвитку не лише кардіологічної, але і ендокринологічної патології (Колеснікова та Козирєва, 2014).

Підвищення секреції інсуліну ПЗ та розвиток атеросклеротичного процесу обумовлений зростанням синтезу ЛПНЩ, що регулюється ферментом ліпопротеїдліпазою (ЛПЛ), знижує вміст ЛПВЩ. Мінімально окислені ЛПНЩ посилюють експресію молекул адгезії (ICAM, VCAM) (Леонтьева та Колесникова, 2008). Тому патогенетичний взаємозв'язок Helicobacter pylori із розвитком АГ та ЦД 2 у хворих на ПВШ та ДПК дозволить виявити початкові зміни судин та ендотелій, що допоможе ефективно підібрати лікування.

Мета роботи - оцінити стан судинно-ендотеліальної функції у хворих на пептичну виразку шлунка та дванадцятипалої кишки у поєднанні з артеріальною гіпертензією і цукровим діабетом типу 2 з подальшою корекцією.

\section{Матеріали та методи}

Обстежено 60 хворих на ПВШ та ДПК у поєднанні з АГ і ЦД2 серед 20 практично здорових осіб (ПЗО) (група І), 16 хворих - на ПВШ та ДПК у поєднанні з АГ і ЦД2 (група ІІ) та 3 них 24 хворих на ПВШ та ДПК (група III). Оцінка судинно-ендотеліальної дисфункції проводилась шляхом визначення sVCAM-1 - Bender MedSystems GmbH, (Австрія), оцінкою ліпідного профілю (Росія).

\section{Результати та їх обговорення}

Оцінюючи вміст молекули адгезії (sVCAM-1) (рис. 1) у хворих без супутньої патології встановлено, що у хворих на ПВШ та ДПК CagA+VacA+ показник у 3,83 рази, а у хворих на ПВШ та ДПК CagA+VacA-/CagA-VacA+ -у 3,05 рази $(p<0,05)$ перевищував вміст у групі П3О ( $p<0,001)$. Проте, вміст даного показника у хворих на ПВШ та ДПК CagA+VacA+ у 1,27 рази $(p<0,05)$ вищий у порівнянні з групою хворих на ПВШ та ДПК CagA+VacA-/CagA-VacAt.

При наявності супутньої патології вміст sVCAM-1 у хворих на ПВШ та ДПК CagA+VacA+ у 6,87 раз $(p<0,05)$ підвищений у порівняно з групою П3О, а у хворих на ПВШ та ДПК CagA+VacA-/CagAVacA + - y 3,37 рази $(p<0,05)$ відповідно. Однак, оцінюючи вплив токсигенних штамів та АГ і ЦД2 на ПВШ та ДПК встановлено, що даний показник у 2,04 рази $(p<0,05)$ підвищений у групі хворих на CagA+VacA+ ПВШ та ДПК у поєднанні з АГ і ЦД 2 у порівнянні з групою хворих на ПВШ та ДПК CagA+VacA-/CagA-VacA у поєднанні з АГ і ЦД2.

За результатами дослідження (табл. 1) виявлено, що у хворих на ПВШ та ДПК CagA+VacA+ ТГ у 1,28 рази $(p<0,05)$ перевищував вміст у групі П3О, а у хворих на ПВШ та ДПК CagA+VacA-/ CagA-VacA+ - у 1,13 раза ( $p<0,05)$. Однак, при наявності супутньої патології вміст ТГ у хворих на ПВШ та ДПК CagA+VacA+ у 1,77 рази $(p<0,05)$ перевищував показник П3О, а у хворих на ПВШ та ДПК CagA+VacA-/CagA-VacA+ - у 1,3 рази $(p<0,05)$ відповідно. Одночасно із підвищенням ТГ спостерігалось підвищення і 3X, що проявлялось збільшенням даного показника у хворих на ПВШ та ДПК при наявності супутньої патології вміст ТГ у хворих на ПВШ та ДПК CagA+VacA+ у 1,47 рази $(p<0,05)$ підвищений порівняно з групою ПзО та у хворих на ПВШ та ДПК CagA+VacA-/CagA-VacA+ - у 1,34 рази $(p<0,05)$ відповідно. Напротивагу, при підвищені ТГ, ЗХ спостерігається достовірне зниження вмісту ЛПВЩ. У хворих на ПВШ та ДПК із АГ і ЦД2 CagA+VacA+ вміст ЛПВЩ знижується у 1,56 рази $(p<0,05)$ зменшений у порівнянні з групою ПЗО, а у хворих на ПВШ та ДПК CagA+VacA-/CagA-VacA+ із АГ і ЦД2 - у 1,55 рази $(p<0,05)$ відповідно. 


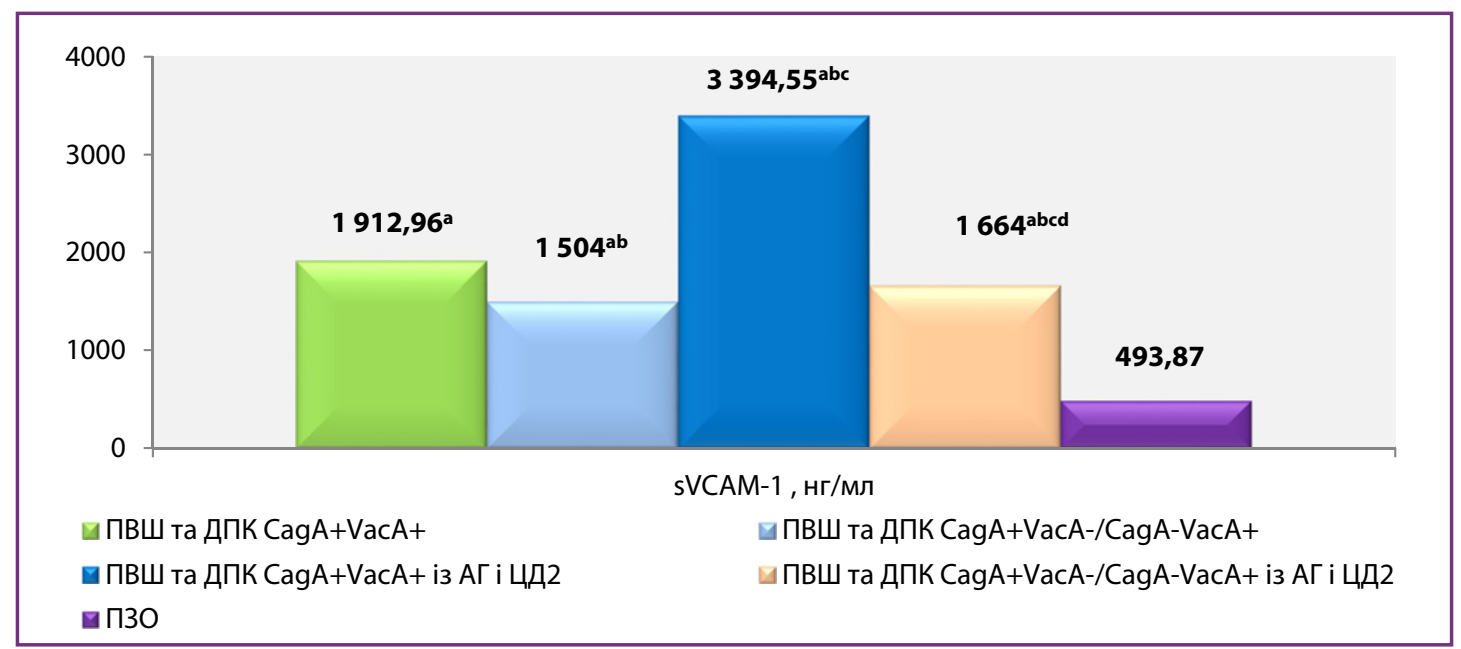

Рисунок 1 Вміст sVCAM-1 в крові при пептичній виразці шлунка та дванадцятипалої кишки у поєднанні з артеріальною гіпертензією і цукровим діабетом типу 2

a - достовірність відмінностей $(p<0,05)$ між показниками в 1-ї, 2-ї, 3-ї, 4-ї груп з 5-ю групою; $\mathrm{b}$ - достовірність відмінностей $(p<0,05)$ між показниками в 1-ї та 4-ї груп; с - достовірність відмінностей $(p<0,05)$ між показниками 2-ї та 4-ї груп; $d$ - достовірність відмінностей $(p<0,05)$ між показниками 3-ї та 4-ї груп

Figure 1 Contents of SVCAM-1 in blood in peptic ulcer and duodenal ulcer in combination with arterial hypertension and diabetes mellitus type 2

a - authenticity differences $(p<0,05)$ between the indices in the 1st, 2 nd, 3rd, 4th group a 5 th group; b - reliability differences $(p<0,05)$ between the indices in the 1 st and 4th groups; $c$ - reliability of differences $(p<0,05)$ figures between 2-nd and 4-th groups; $\mathrm{d}$ - reliability of differences $(p<0,05)$ between the indicators of the 3 rd and 4th groups

Таблиця 1 Показникиліпідного профілюухворих на пептичну виразкушлунка та дванадцятипалої кишки у поєднанні з артеріальною гіпертензією і цукровим діабетом типу $2, \mathrm{M} \pm \mathrm{m}$

Table 1 The lipid profile in patients with peptic ulcer of stomach and duodenal ulcers combined with arterial hypertension and diabetes mellitus type $2, \mathrm{M} \pm \mathrm{m}$

\begin{tabular}{|c|c|c|c|c|c|}
\hline \multirow[t]{3}{*}{ Показник } & \multicolumn{5}{|c|}{ Групи обстежених } \\
\hline & \multicolumn{2}{|c|}{ хворі на ПВШ та ДПК } & \multicolumn{2}{|c|}{$\begin{array}{c}\text { хворі на ПВШ та ДПК у поєднанні } \\
\text { з АГ і ЦД2 }\end{array}$} & \multirow{2}{*}{$\begin{array}{c}\text { п30 } \\
\left(\begin{array}{c}5-\mathbf{~ г р у п а ) ~} \\
n=30\end{array}\right.\end{array}$} \\
\hline & $\begin{array}{c}\text { CagA+VacA+ } \\
(1-a \text { грyпa) } \\
n=28\end{array}$ & $\begin{array}{c}\text { CagA+VacA-/CagA- } \\
\begin{array}{c}\text { VacA+(2-a rpyna) } \\
n=20\end{array}\end{array}$ & $\begin{array}{c}\text { CagA+VacA+ } \\
\text { (3-я група) } \\
n=22\end{array}$ & $\begin{array}{c}\text { CagA+VacA-/CagA- } \\
\text { VacA+(4-a rpyna) } \\
n=38\end{array}$ & \\
\hline $\begin{array}{l}\text { Загальний } \\
\text { холестерин, } \\
\text { ммоль/л }\end{array}$ & $4,99 \pm 0,28^{a}$ & $4,66 \pm 0,27^{\mathrm{ab}}$ & $6,11 \pm 0,24^{\mathrm{abc}}$ & $5,6 \pm 0,2^{\mathrm{abcd}}$ & $4,17 \pm 0,29$ \\
\hline $\begin{array}{l}\text { Тригліцериди, } \\
\text { ммоль/л }\end{array}$ & $170,54 \pm 8,08^{a}$ & $151,44 \pm 3,15^{\mathrm{ab}}$ & $236,90 \pm 13,14^{\mathrm{abc}}$ & $173,68 \pm 5,48^{\mathrm{acc}}$ & $133,62 \pm 4,39$ \\
\hline лПВЩ, ммоль/л & $0,93 \pm 0,09^{a}$ & $1,03 \pm 0,09^{\mathrm{ab}}$ & $0,83 \pm 0,07^{\mathrm{abc}}$ & $0,86 \pm 0,04^{\mathrm{abcd}}$ & $1,33 \pm 0,13$ \\
\hline лПнщ, ммоль/л & $2,88 \pm 0,27^{\mathrm{a}}$ & $2,85 \pm 0,12^{\mathrm{ab}}$ & $3,51 \pm 0,14^{\mathrm{abc}}$ & $3,49 \pm 0,16^{\mathrm{abcc}}$ & $2,28 \pm 0,42$ \\
\hline IA & $4,91 \pm 0,48^{\mathrm{a}}$ & $3,81 \pm 0,55^{\mathrm{ab}}$ & $6,49 \pm 0,71^{\mathrm{abc}}$ & $5,27 \pm 0,25^{\mathrm{abcd}}$ & $2,68 \pm 0,53$ \\
\hline
\end{tabular}

а -достовірність відмінностей ( $p<0,05)$ між показниками в 1-ї, 2-ї, 3-ї, 4-їгруп з 5-ю групою; b-достовірність відмінностей $(p<0,05)$ між показниками в 1-ї та 4-ї груп; с - достовірність відмінностей $(p<0,05)$ між показниками 2-ї та 4-ї груп; d - достовірність відмінностей $(p<0,05)$ між показниками 3-ї та 4-ї груп 
При зниженні вмісту ЛПВЩ спостерігається підвищення ЛПНЩ, який у 1,26 рази у хворих на ПВШ та ДПК CagA+VacA+ перевищував вміст у групі ПЗО ( $p<0,05)$, а у хворих на ПВШ та ДПК CagA+VacA-/CagA-VacA+ - у 1,25 рази $(p<0,05)$. Проте, порівнюючи групи хворих на ПВШ та ДПК при різних комбінаціях штамів, достовірного підвищення не відмічалось. При поєднанні із супутньою патологією даний показник підвищувався у 2,62 рази $(p<0,05)$ та у 2,64 рази $(p<0,05)$.

Оцінивши дані показники ліпідного обміну встановлено, що найвищий IA сягав у хворих на ПВШ та ДПК CagA+VacAt, що у 1,56 рази перевищував вміст у групі П3О $(p<0,05)$ та при наявності супутньої патології у хворих на ПВШ та ДПК CagA+VacAt, що у 1,97 рази $(p<0,05)$ відповідно. Враховуючи зміну порушення ліпідного профілю та вмісту молекули адгезії крім запропонованої дієти при даному захворюванні необхідно приймати насіння льону у вигляді настойок, узварів тощо. Основними властивостями його $\epsilon$ покращення перистальтики, насичення організму різними амінокислотами, марганцем, калієм, магнієм і незамінними жирними кислотами Омега-3, Омега-6 і Омега-9. Лігнано, що присутній в оболонці, виконує роль антиоксидантної системи та знижує рівень холестерину при тривалому прийомі.

\section{Висновки}

Перебіг ПВШ та ДПК у поєднанні з АГ і ЦД2 обумовлений порушенням ліпідного обміну та молекули адгезії, найбільші зміни виявлені при наявності комбінації штамів CagA+VacA+ (підвищення вмісту sVCAM-1 у 1,27 рази, три гліцерину - у 1,28 рази, ЛПНщ - у 2,64 рази на фоні зниження ЛПВЩ - у 1,58 рази). Оскільки, основними лікувальними властивостями льону $\epsilon$ покращення антиоксидантної системи та ліпідного обміну, а саме нормалізація рівня холестерину при тривалому прийомі. Тому, разом із хелікобактерною терапією, рекомендовано приймати до раціону кожного хворого насіння льону для нормалізації ліпідного обміну, запобігання розвитку ускладнень з боку судинно-ендотеліальної функції.

\section{Література}

Бабак, О., Фадєєнко, Г., Ярмиш, Н., Молодан, В. 2011. Залежність змін показників вуглеводного обміну та антропометричних показників від генотипу гена рецептора AT1R у хворих на артеріальну гіпертензію в поєднанні з інсулінорезистентністю. Український терапевтичний журнал, № 2, с. 20-25.

Колеснікова, О, Козирєва, Т. 2014. Інфекція Helicobacter pylori - лише гастроентерологічна проблема? Сучасна гастроентерологія, № 6 (80), с. 137-141.

Леонтьева, В, Колесникова, И. 2008. Болевой синдром у больных язвенной болезнью в сопоставлении с интрагастральным рН. Клиническая медицина, № 8, с. 50-53. 